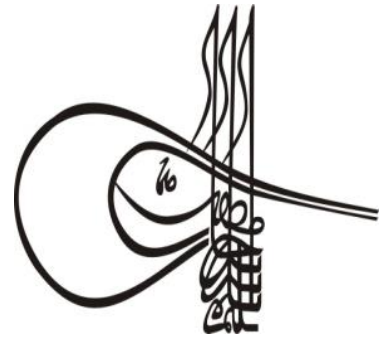

Received/Geliş: 10.06.2019

Gor Report Dates/Rapor Tarihleri: Referee 1 (26.07.2019)-Referee 2 (29.07.2019)

\section{Turkigh Studies \\ Social Sciences}

Volume 14 Issue 4, 2019, p. 1885-1904

DOI: 10.29228/TurkishStudies.23481

ISSN: 2667-5617

Skopje/MACEDONIA-Ankara/TURKEY

Research Article / Araştırma Makalesi

Article Info/Makale Bilgisi

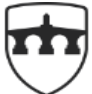

INTERNATIONAL BALKAN UNIVERSITY

EXCELLENCE FOR THE FUTURE IBU.EDU.MK

\Accepted/Kabul: 10.08 .2019

This article was checked by turnitin.

\title{
TÜRKIYY'DE ULUSAL KANALLARDA ŞİDDET OLGUSUNUN SUNUMU: ANA HABER BÜLTENLERİ ÜZERİNE BİR İNCELEME
}

Hüseyin YAŞA*

\begin{abstract}
öz
Medya ve şiddet konusu medya teorilerinde ve çalışmalarında geniş yer tutan önemli bir konu olmasından dolayı şiddetin, birçok yönüyle ilgili farklı zamanlarda çalışmalar yapılmaktadır. Medyada şiddetin görünürlüğü ilk gazete ile başlayarak daha sonradan televizyon üzerinde çalışmaların yoğun olarak yapıldığı söylenebilir. Televizyon bugün kolay ulaşılabilen ve yaygın kullanılan önemli bir görsel ve işitsel kitle iletişim aracıdır. Televizyon ekranlarında her geçen gün etkisini daha da artıran şiddet ögelerini dizilerde, kadın programlarında, yarışma programlarında, talk-show programlarında, çizgi filmlerde ve hatta ana haber bültenlerinde de şiddet içeren çok sayıda unsur toplumun her kesmine sunulmaktadır. Bu noktada televizyon özelinde suç ve şiddete dikkat çekmeye yönelik yayıncılık anlayışının sonucunda gerçek yaşamda gasp, darp, cinayet, intihar, işkence gibi çeşitli şiddet olaylarının artması, medyanın öğretmesi ve duyarsızlaştırması, dış dünyanın korkulacak bir yer olarak alg1 yaratması, şiddetin problem çözme olarak benimsenmesi gibi televizyonun bir takım toplum üzerindeki etkisi olduğunu söylenebilir. Bunun yanı sıra son yıllarda medyada şiddet haberlerine oldukça fazla yer verilmesi nedeniyle, bu konuda tartışmalarda sürekli gündemde kalmakta; aynı zamanda bu konular üzerinde yapılan araştırmalarda artmaktadır. Bu çalışmada ana Haber bültenlerinde sunulan şiddet örüntülerinin etkisini incelemek amacıyla Türkiye'deki ulusal 6 kanalda (Atv, Show Tv, Star Tv, Kanal D, Fox, Kanal 7) şiddet olayları mesaj sistem çözümlemesi ile analiz edilerek somut sonuçlar ortaya koymak amaçlanmaktadır.
\end{abstract}

Anahtar Kelimeler: Medya, Şiddet, Televizyon Haberciliği, Ana Haber Bültenleri, Mesaj Sistem Çözümlemesi 


\title{
A PRESENTATION OF VIOLENCE CASES ON THE NATIONAL TV CHANNELS IN TURKEY: A STUDY ON THE MAIN NEWS BULLETINS
}

\begin{abstract}
Since the issue of media and violence is an important topic that covers a wide range of media theories and studies, studies are carried out on many aspects of violence at different times. The presence of violence in the media first starts with newspaper, then it can be said that the work on television is intense. Television is an easily accessible and widely used visual and audio mass communication medium today. On TV screens, elements of violence that increase their influence day by day are presented to every segment of the society with violence, in series, women's programs, competition programs, talk shows, cartoons and even in the main news bulletins. At this point, as a result of the broadcasting approach aimed at drawing attention to crime and violence in television, the increase in various incidents such as extortion, assault, murder, suicide, torture, the media's teaching and desensitization, the perception of the outside world as a place to be feared and the adoption of violence as problem solving. It can be said that television has an impact on a number of communities. In addition to the fact that there has been a lot of media coverage of violence in recent years, it is always on the agenda in discussions about this issue; it is also increasing in research on these issues. In this research, with the aim of examining the impact of violence patterns presented in the main news bulletins, it is aimed to demonstrate tangible results by analyzing violence incidents system message analysis in the 6 national channels in Turkey (Atv, Show TV, Star TV, Kanal D, Fox, Kanal 7).
\end{abstract}

\section{STRUCTURED ABSTRACT}

While violence, which is as old as the history of humanity, has been an instrument of defense of individuals against nature in the past, when we look at it, it has become an instrument that individuals use for their own kind. The easier it is to detect violence today, the more difficult it is to draw a framework by defining it as a particular concept. For this reason in the world and in Turkey, academics and researchers are being told in various forms of violence and define. At this point, because violence is a phenomenon that has many different aspects, how to evaluate the violence varies depending on the perpetrator, the victim and the society.

Violence, which has become a social problem, has become a phenomenon that has made its impact increasingly visible throughout the world. Today, it can be said that everyone has a tendency to violence and apply to the phenomenon of violence. Especially when the studies in the literature are examined, it is seen that the violence incidents seen on young people are becoming more and more common day by day. Mass media is the biggest and most fundamental part of the spread of violence in all areas of such societies. The rate of violence introduced in the media to the audience is increasingly visible. Especially television series, movies, women's programmes, cartoons, main news bulletins and so on. 
In such publications, the phenomenon of violence is found to a large extent.

Purpose of the study, the violence presented among mass media tools especially in the television leaves very significant impacts on the lives of individuals. At this point, such factors as whether the violence is a crime, whether the perpetrator or the victim is famous, whether the perpetrator or the victim know each other, the status of the perpetrator and victim, the place of the incident of violence, time of the violence, violence tools and forms the number of violence have been investigated.

When looked into the methodology of the study; the message system solutions used in the study forms the basis of the solutions of breeding, anda re the second stage of cultural indicators project. Message system solutions, with respect to forming a basis for breeding solutions, are a sources of fundamental importance for the questions formed.

The universe of these studies investigating the violence on national TV channels in Turkey are located in the main news bulletin broadcast media in Turkey. Because of the size of the universe in question, a sample was created within the framework of the principles of sampling theory. In this direction; a ) Channels to be searched b) Time interval to be searched and c) Main newsletters to be searched are determined. In line with the universe and sample created; Atv, Star Tv, Show Tv, Kanal D, Fox Tv, Kanal 7 channels constitute the universe of the research and the main news bulletins published for 5 days between 01.10.2018 - 05.10.2018, which were selected through purposive sampling, constitute the sample of this research.

When we evaluate the findings of the research, the concrete data obtained are; In the main news bulletins of Atv, Star, Show TV, Kanal D, Fox, Kanal 7 channels for a week (1.10.2018 - 5.10.2018), it is observed that the content of violence was seen most on 5.10.2018 with the rate of $24.10 \%$ in contrast to other days.

In the continuity category of the message system analysis related to the main news bulletins, it has been determined that the violence in the news is not presented separately but continuously. It was revealed in the bulletins that the news of violence did not contain the element of humor and was constantly given in serious tone. It was seen that the violence reports were mostly not accidents $(61.1 \%)$ and that they were intentional acts.

Of the 208 perpetrator news articles, 88 were found to be officially seen as $43.2 \%$ of the actors (police, soldiers, security officers, etc.), which were considered as law units. In addition to the fact that in 120 news out of 208, where law units are located in acts of violence, the police cannot be coded as perpetrator actors, while the news that the police actors are actors, the violence in the 8 news stories is subjected to violence in the 5 news stories and the police is not subjected to violence in 68 news stories. While $65.4 \%$ of the violence reports presented in the main news bulletins are criminal, $34.1 \%$ are not criminal. In the news, it can be said that it is effective to include the events (terror, martyr news, war news) that were effective during the period in which the crime quality was high. Compared to other channels, Show TV is the channel that hosts the most criminal 
elements in this direction, while Atv and Fox Tv is the channel that contains the least criminal elements.

In the news of violence, the section examined whether the actors know each other is $1.4 \%$ non-codable. When we look at the total news, $92.3 \%$ of the perpetrators and the victims of violence do not know each other. Violence among people who knew each other was determined as $6.3 \%$. From this point of view, we can conclude that violence occurs most frequently among individuals who do not know each other.

$97.6 \%$ of the actors who used violence in the period when the news was chosen were not famous and $1.4 \%$ were famous. On the other hand, $90.4 \%$ of the actors who were subjected to violence were not famous and $1.0 \%$ were famous. When we look at the occupational distributions of the actors in the perpetrator news category; $84,6 \%$ of the 176 news items were found to be non-codable. When we look at the distribution of occupations in the category of actors who are subjected to violence; It was found that $79.9 \%$ of the 166 news items were non-codable. In the light of the analysis, no significant differentiation was found in the occupations of individuals as the practitioner and the victim of violence. In addition, it should be noted that in the violence news that is examined, collective knowledge of perpetrator acts is not neglected, and in most of the news, practitioners and victims of violence are not provided with occupational information. According to the social class and status categories, it was concluded that those who use violence and who are subjected to violence cannot be coded. When the news of violence is examined in terms of gender as the perpetrator and the perpetrator of violence, it is concluded that there are male actors in both categories.

When we look at the place where the most perpetrator incidents occur; While Istanbul came in at a rate of $20.7 \%$, according to the settlement where the events took place, it was seen that 158 news took place in the city center with a rate of $76.0 \%$, and 33 news reported that $15.9 \%$ of the violence occurred in rural areas. According to the findings obtained according to the time period of the incidents of violence, it was determined that the incidents of violence occurred in the daytime hours at a rate of $80.3 \%$, as seen in the 167 news. There is also the possibility that perpetrator incidents may occur due to interventions resulting from conflicts and tensions due to the intensification of relations between individuals during the day.

Most of the perpetrator incidents were armed. In the channels examined during the period, it was seen that the intentional consequences of severe and serious acts of violence on human life with weapons were deliberate. In the news examined in the main news bulletins, it was found that when violence was examined, there were at least 1 , at most 60 and an average of 9.16 scenes of violence. On the other hand, when the news was evaluated on a channel-specific basis, the highest frequency of violence presentation was seen on Kanal 7 channel within 5 days, while the violence scene was observed at least on Fox TV.

Based on the findings and conclusions of the perpetrator news coverage in the visual press and based on the researcher's experience in the research process, it is possible to make the following recommendations: 
A national awareness of violence should be created for individuals who graduate from universities by disseminating the units that conduct studies on violence both in our daily lives and in the media in all universities. Similarly, violence courses should be expanded in communication faculties and students should be able to graduate fully in the field of violence, especially in the media.

In the news, the tendency to internalize the violence in the society and not to show such behaviors as a normal, ordinary situation, as well as the tendency to report them as sensational and magazine should be avoided.

If we take violence in more general terms, it is observed that the violence against animals during the coding of violence news in almost every channel in the main news bulletins, especially within the scope of the research, cannot be remembered. At this point, it is necessary to develop a proposal to prevent violence against all living things (plants, trees, flowers). Based on Gerbner's definition of violence, acts of violence against animals and various other living things were not included in the study. Since television constitutes a large part of individuals' lives, acts of violence against animals, which have become one of their major problems, have a profound impact on society. At this point, it can be said that acts of violence against animals should not be ignored.

In line with responsible broadcasting, television organizations should not include any broadcasts that may cause them to be adversely affected, especially during the hours of the screen. It is important not to visualize perpetrator issues and events as much as possible and not to publish them repeatedly. Because it can be said that it makes people, especially children, insensitive to fear, anxiety and many other negative situations. In conclusion, it is important for individuals, broadcasters and RTÜK to continue their activities in a collaborative way in order to prevent the negative effects of violence on television.

This research of national broadcast television channels in Turkey, located in the main news bulletin consists of analyzing the element of violence. The findings are thought to be useful for the violence researches that will be conducted on television.

Keywords: Media, Violence Television Journalism, Main Newsletters, Message System Analysis

\section{Giriş}

İnsanlık tarihi kadar eski bir kavram olan şiddet, geçmiş dönemlerde bireylerin doğaya karşı kendisine bir savunma aleti olurken, günümüzde baktığımız zaman bu şiddet aleti bireylerin kendi cinsi için kullanır duruma gelmiştir. Bugün şiddeti saptamamız ne kadar kolaysa, belli bir kavram olarak tanımlayarak çerçeve çizmekte o kadar zordur. Bu sebepten ötürü Dünyada ve Türkiye'de akademisyenler ve araştırmacılar şiddeti çeşitli şekillerde anlatmakta ve tanımlamaktadırlar. Bu noktada şiddet çok farklı yönleri bulunan bir olgu olduğundan dolayı, şiddetin nasıl değerlendirileceği şiddeti uygulayana, şiddete maruz kalana ve içinde bulunulan toplumdan topluma değişmektedir.

Toplumsal bir problem haline gelen şiddet, tüm dünyada etkisini gittikçe daha görünür k1lan bir olgu olmaya başlamıştır. Bugün günümüzde 7'den 70'e herkesin şiddete eğilimi olduğunu ve şiddet olgusuna başvurduğunu söylenebilir. Özellikle alanyazında yapılan çalışmalara bakıldığında gençler 
üzerinde görülen şiddet olaylarının gün geçtikçe daha da çok rastlanılabilir bir durum haline geldiği görülmektedir. Şiddetin bu denli toplumların bütün alanlarında yayılmasındaki en büyük ve en temel pay kitle iletişim araçlarıdır. Medyada izleyiciye yönelik dolaşıma sokulan şiddet oranı gittikçe daha fazla görünür olmaktadır. Özellikle televizyon nezdinde diziler, filmler, kadın programları, çizgi filmler, ana haber bültenleri vb. gibi yayınlarda şiddet olgusu kendine büyük oranda yer bulmaktadır.

Türk Dil Kurumu Türkçe Sözlüğ̈̈’ne göre şiddet kelimesi; "Bir hareketin, bir gücün derecesi, yeğinlik, sertlik, karşıı görüşte olanlara kaba kuvvet kullanma, duygu veya davranışta aşırılık" olarak tanımlanmıştır.

Gerbner ve Gross'a göre (akt. Özer, 2007, s.113) şiddet; "Fiziksel gücün silahlı ya da silah kullanmadan, kişinin kendisine ya da başkalarına karşı, kurbanın kendi rızası dışında, acı verecek şekilde incitilmesi, öldürülmesi ya da olayın bir parçası olarak kurban olacak derecede tehdit edilmesi unsurlarının açık bir ifadesidir." İnandırıcı şiddet sonuçları doğurmayan tehditler, mimikler, sözlü saldırılar, jestler şiddet olarak kodlanamazken (Gerbner vd., 1980, s. 11), dramatik eylemler olarak daima belli karakterleri kurban eden kaza ve doğal şiddet olayları, şiddet olarak kodlanmaktadır (1980, s. 12; Morgan, 1984).

Ancak baktığımız zaman şiddetin meydana getirmiş olduğu zararları fiziksel olarak nitelemek eksik bir yaklaşım olacaktır. Şiddet pek çok açıdan geri dönüşü mümkün olmayan, toplumsal veya bireysel olarak "yok olma" ile sonuçların durumların yaşanmasına neden olmaktadır. $\mathrm{Bu}$ bağlamda şiddetin sadece fiziksel olarak ele alınamayacağını ve fiziksel şiddetten oluşmadığı sonucuna ulaşılmaktadır. Şiddetin, meşru-yasal şiddet, devletler ve büyük gruplar arası şiddet, gayrimeşruyasadışı şiddet, bireysel ve örgütlü şiddet, araçsal, duygusal ve düşmanca şiddet, hayvanlara ve başka nesnelere yönelik şiddet, kendine yönelik şiddet, dolaylı şiddet, sembolik şiddet, kötü muamele, konvansiyel şiddet, dayak, taciz gibi pek çok türden meydana geldiği söylenebilir (Gümüş, 2006, s. 13$35)$.

Araştırmacılar medyadaki şiddeti doğal, suni, gerçek ve varsayıma dayananlar olmak üzere dörde ayrıldığını söyleyebiliriz. Gerçek şiddet fiziksel ve psişik zarar verme amacına yöneliktir ya da böyle bir zarar vermenin yarattığı etkilerin medya tarafından halka sunulması olarak tanımlanabilir. Varsayılan şiddet, bu tür davranışların bir ön koşul olarak medya tarafindan halka sunulması demektir. Doğal şiddet, gerçek şiddet olaylarının medya tarafından gösterilmesi, suni şiddetse ise, örneğin çizgi filmlerle gösterilen, gerçek dış şiddet türleridir. Bireysel şiddet, bir bireyin başka bir bireye ya da canlı bir varlığa ya da eşyaya karşı fiziksel ya da ruhsal zarar verme amacıyla yaptı̆̆ girişimlere verilen genel ad olarak tarif edilebilir (Kunczik, 1994:117-119).

\section{Amaç}

Kitle iletişim araçları içerisinde özellikle televizyonda sunulan şiddet, bireylerin hayatlarında çok önemli izler bırakmaktadır. Bu noktada suç ve şiddet örüntülerini ana haber bültenlerinde nasıl sunulduğunun yanı sıra yayınlanan haberler mesaj sistem çözümlemesi yoluyla ele alınan tarihler arasında suç ve şiddet örüntülerinin hangi kanalda daha fazla görünür olduğu, şiddetin tonu, şiddete katılanların sayısı, şiddetin suç olup olmadığı, şiddetçinin ve uğrayanın ünlü olup olmadığı, şiddetçinin veya şiddete uğrayanın birbirlerini tanıyıp tanımadıkları, şiddetçinin ve uğrayanın statüleri, şiddetin gerçekleştiği olay yeri, şiddetin gerçekleştiği zaman, şiddet aleti ve biçimi, şiddet adeti gibi birtakım unsurlar araştırılmıştır.

\section{Metodoloji}

Amaçlı örneklem yoluyla belirlenen 01.10.2018 - 05.10.2018 tarihleri arasında Atv, Star, Show, Kanal D, Fox, Kanal 7'de yayınlanan ana haber bültenleri 5 gün süre ile incelenmiştir. Yayınlanan haberler mesaj sistem çözümlemesi yoluyla ele alınan tarihler arasında suç ve şiddet örüntülerinin hangi kanalda daha fazla görünür olduğu, şiddetin tonu, şiddete katılanların sayısı, şiddetin suç olup olmadığı,

\section{Turkish Studies - Social Sciences}

Volume 14 Issue 4, 2019 
şiddetçinin ve uğrayanın ünlü olup olmadığı, şiddetçinin veya şiddete uğrayanın birbirlerini tanıyıp tanımadıkları, şiddetçinin ve uğrayanın statüleri, şiddetin gerçekleştiği olay yeri, şiddetin gerçekleştiği zaman, şiddet aleti ve biçimi, şiddet adeti gibi birtakım unsurlar araştırılmıştır.

Mesaj sistem çözümlemesi yetiştirme çözümlemesine temel oluşturmaktadır ve Kültürel Göstergeler Projesi'nin ikinci aşamasıdır. Mesaj sistem çözümlemesi, önemini Yetiştirme çözümlemesine temel oluşturan sorulara kaynaklık etmesinden almaktadır (Gerbner, 1990, s.253'den akt. Özer 2004, s.57). Yöntem olarak mesaj sistem çözümlemesinin seçilmesinin nedeni, analiz sonucunda elde edilen verilerin birtakım anlamlarının tespit edilebilmesi için sağladığı yorumlama imkanıdır.

\section{Evren ve Örneklem}

Türkiye'deki ulusal kanallarda şiddet olgusunu inceleyen bu araştırmanın evrenini Türkiye'deki görsel basın içerisinde yer alan ana haber bültenleri oluşturmaktadır. Söz konusu evrenin büyüklüğü nedeniyle örneklem kuramı ilkeleri çerçevesinde örneklem oluşturulmuştur. Bu doğrultuda; a) araştırma yapılacak kanallar b) araştırma yapılacak zaman aralığı ve c) araştırma yapılacak ana haber bültenleri belirlenmiştir. Oluşturulan evren ve örneklem doğrultusunda; Atv, Star Tv, Show Tv, Kanal D, Fox Tv, Kanal 7 kanalları araştırmanın evrenini, amaçlı örneklem yoluyla seçilen 01.10.2018 - 05.10.2018 tarihleri arasında 5 gün süre ile yayınlanmış ana haber bültenleri ise bu çalışmanın örneklemini oluşturmaktadır.

\section{Bulgular Ve Değerlendirme}

Tablo 1: Tarih

\begin{tabular}{c|c|c}
\hline Tarih & Say1 & Yüzde \\
\hline 5.10 .2018 & 51 & 24,5 \\
\hline 1.10 .2018 & 45 & 21,6 \\
\hline 4.10 .2018 & 42 & 20,2 \\
\hline 2.10 .2018 & 39 & 18,8 \\
\hline 3.10 .2018 & 31 & 14,9 \\
\hline Toplam & 208 & 100,0 \\
\hline
\end{tabular}

Türkiye'de ulusal yayın yapan Atv, Star, Show Tv, Kanal D, Fox, Kanal 7 kanallarında bir hafta süresince ele alınan (1.10.2018 - 5.10.2018) tarihleri arasında yayınlanan ana haber bültenlerinde diğer tarihlere oranla şiddet içeriğinin en çok 5.10.2018 tarihinde \%24,5 oranında olduğu söylenebilir.

Tablo 2: Kanallar

\begin{tabular}{c|c|c}
\hline Kanallar & Sayı & Yüzde \\
\hline Kanal 7 & 72 & 34,6 \\
\hline Show Tv & 49 & 23,6 \\
\hline Star Tv & 45 & 21,6 \\
\hline Atv & 18 & 8,7 \\
\hline Kanal D & 18 & 8,7 \\
\hline Fox & 6 & 2,9 \\
\hline Toplam & 208 & 100,0 \\
\hline
\end{tabular}

Çalışmada elde edilen bulgulara göre, şiddet ögelerinin en çok Kanal 7 ana haber bülteninde görsel olarak şiddetin sunumunun gerçekleştiği söylenebilir. Örneklemin ele alındığı tarihler arasında 
şiddet haberlerinin sunumunda şiddet ögelerinin en az Fox Tv ana haber bülteninde olduğu sonucuna ulaşılmıştır. Çünkü Fox Tv de yayınlanan haberlerin içerikleri incelenen günler baz alındığında daha çok siyasi ve ekonomi içerikli olduğu görülmektedir.

Tablo 3: Katılanların Sayis1

\begin{tabular}{c|c|c}
\hline Katılanların Sayıs1 & Say1 & Yüzde \\
\hline Kodlanamaz & 25 & 12,0 \\
\hline Sayılamaz & 110 & 52,9 \\
\hline 1 & 45 & 21,6 \\
\hline 2 & 16 & 7,7 \\
\hline 3 & 3 & 1,4 \\
\hline 4 & 5 & 2,4 \\
\hline $5+$ & 4 & 2,0 \\
\hline Toplam & 208 & 100,0 \\
\hline
\end{tabular}

İncelenen 208 şiddet haberleri içerisinde yer alan aktörlerin, en çok \%52,9 oranında sayılamayacak kadar fazla olduğu sonucu çıkmıştır. Belirtilen tarih aralığında incelenen örneklem süresince sayılamayacak kadar çok şiddet olaylarının fazla çıkması; toplu bir şekilde (Terör olayları, şehit haberleri, savaş haberleri) gibi bir takım olayların sebep olduğu ileri sürülebilir.

Tablo 4: Kaza

\begin{tabular}{c|c|c}
\hline Kaza & Say1 & Yüzde \\
\hline Kasten & 127 & 61,1 \\
\hline Kaza & 49 & 23,6 \\
\hline Doğal Afet & 20 & 9,6 \\
\hline Kodlanamaz & 8 & 3,8 \\
\hline Karışı & 4 & 1,9 \\
\hline Toplam & 208 & 100,0 \\
\hline
\end{tabular}

İncelenen dönemdeki haber bültenlerinde sunulan şiddet olaylarının çok büyük bir oranda \%61,1 kasten gerçekleştirilmiş olduğu söyleyenebilir. İncelenen toplam 208 haber içerisinde; 49 haberde şiddetin kasten olmadığı \%23,6 oranında kaza olarak gerçekleştiğini, 20 haberde şiddetin \%9,6 oranında doğal afet sonucu meydana geldiği, 8 haberde şiddetin \%3,8 oranında kodlanamaz olarak işaretlendiği, 4 haberde ise şiddetin $\% 1,9$ oranında karışık olarak gerçekleştirildiği sonucuna ulaşılmıştır.

Tablo 5: Kanun Birimleri

\begin{tabular}{c|c|c}
\hline Kanun Birimleri & Say1 & Yüzde \\
\hline Resmi Görünür & 88 & 42,3 \\
\hline İkisi de Görünmüyor & 78 & 37,5 \\
\hline İkisi de Görünür & 24 & 11,5 \\
\hline Kodlanamaz & 15 & 7,2 \\
\hline Özel Görünür & 3 & 1,4 \\
\hline Toplam & 208 & 100,0 \\
\hline
\end{tabular}


Günümüzde şiddet olgusu aile yaşamında, işyerlerinde, arkadaşlık ilişkilerinde, kitle iletişim araçlarında kısacası gündelik yaşantımızda önemli bir toplumsal sorun olarak karşımıza çıkmaktadır. $\mathrm{Bu}$ noktada şiddet davranışlarını toplum içerisinde düzenleyen ve bir takım aksaklıkları gidermede görevli olarak konumlandırılan kanun birimleri, şiddet olaylarındaki oynadığı role ilişkin olarak toplam 208 haber içerisinde 88 haberde \%42,3 oranında resmi görünür olarak yer aldıkları söylenebilir. Belirtilen tarih aralığında incelenen toplam 208 haberde kanun birimlerinin toplumda yer alan şiddet ögelerinin sebep olduğu olumsuzlukları giderme noktasında aktif olarak rol aldığı söylenebilir. 78 haberde $\% 37,5$ oranında kanun birimleri resmi ve özel olarak görünmediği, 24 haberde $\% 11,5$ oranında hem resmi hem de özel olarak göründüğ̈̈, 15 haberde $\% 7,2$ oranında kodlanamadığını, 3 haberde ise $\% 1,4$ oranında özel olarak görünür olduğu sonucuna ulaşılmıştır.

Tablo 6: Polis

\begin{tabular}{c|c|c}
\hline Polis & Say1 & Yüzde \\
\hline Kodlanamaz & 120 & 57,7 \\
\hline Ne Uyguluyor Ne Uğruyor & 68 & 32,7 \\
\hline Şiddet Uyguluyor & 8 & 3,8 \\
\hline Hem Uğruyor Hem Uyguluyor & 7 & 3,4 \\
\hline Şiddete Uğruyor & 5 & 2,4 \\
\hline Toplam & 208 & 100,0 \\
\hline
\end{tabular}

İncelenen toplam 208 haberde polislerin, şiddet haberlerinde konuşlanış şekillerine bakarsak; 120 haberde \%57,7 oranında polisin şiddet aktörü olarak kodlanamayacağı çıkmıştır. 208 haber içerisinde polislerin aktör olarak kodlanabildiği haberlere bakıldığında; 68 haberde \%32,7 oranında polis şiddet uygulamamakta ve uğramamakta, 8 haberde $\% 3,8$ oranında polis şiddet uygulamakta, 7 haberde $\% 3,4$ oranında polis hem şiddete uğruyor hem de şiddete uğruyor, 5 haber ise $\% 2,4$ oranında polis şiddete uğruyor sonucuna ulaşılmıştır. Toplumsal olaylarda toplumun huzuru ve güvenliğini sağlamada yetkili olan emniyet birimleri şiddetin meydana geldiği olaylarda müdahalede bulunmak zorunda kaldığı gibi, olaylara verilen tepkilerlerde de güç kullanmak durumunda bulunduğu söylenebilir.

Tablo 7: Suç

\begin{tabular}{c|c|c}
\hline Suç & Sayı & Yüzde \\
\hline Suç & 136 & 65,4 \\
\hline Suç Değil & 71 & 34,1 \\
\hline Kodlanamaz & 1 & 0,5 \\
\hline Toplam & 208 & 100,0 \\
\hline
\end{tabular}

İncelenen haberler kapsamında şiddetin belirli bir suç (cinayet, bıçaklama, silahlı saldırı, tecavüz vb. gibi) teşkil ettiği 136 haberde en yüksek \%65,4 oranına ulaşılırken, en az oran $\% 0,5$ ile 1 haberde suç unsurunun varlığı tespit edilememiştir. Analiz edilen haberlerin 71 'inde ise \%34,1 oranında şiddet haberlerinin suç unsuru (sel, hortum, fırtına, yıldırım, heyelan, deprem vb. gibi) teşkil etmediği sonucuna ulaşılmıştır. Genel olarak bakıldığı zaman ana haber bültenlerinde yayınlanan şiddet haberlerinin suç unsuru teşkil ettiği gözlenmiştir. 
Tablo 8: Kanallar ve Suç

\begin{tabular}{c|c|c|c}
\hline Kanallar ve Suç & Kodlanamaz & Suç & Suç Değil \\
\hline Show Tv & - & 43 & 6 \\
\hline Kanal 7 & - & 40 & 32 \\
\hline Star Tv & - & 27 & 18 \\
\hline Kanal D & - & 14 & 4 \\
\hline Atv & 1 & 6 & 11 \\
\hline Fox Tv & - & 6 & 71 \\
\hline Toplam (208) & 1 & 136 & - \\
\hline
\end{tabular}

Ele alınan dönemler kapsamında kanallar özelinde şiddet haberlerinin suç teşkil edip, etmediğine bakarsak; toplam 208 haberde, Atv kanalının 1 haberinde $\% 0,5$ oranında suç unsurunun varlığ tespit edilememiş kodlanamaz olarak işaretlenmiştir. Şiddet haberlerinde suç teşkil edecek kanalların haberlerine bakıldığında; Show Tv kanalının 43 haberde \%20,7 oranında, Kanal 7 kanalının 40 haberde \%19,2 oranında, Star Tv kanalının 27 haberde \%13,0 oranında, Kanal D kanalının 14 haberde \%6,7 oranında, Atv kanalının 6 haberde \%2,9 oranında, Fox kanalının ise 6 haberinde \%2,9 oranında şiddet olaylarının suç teşkil ettiği sonucuna ulaşılmıştır. Şiddet haberlerinde suç teşkil etmeyen kanalların haberlerine bakıldığında; Show Tv kanalının 6 haberinde \%2,9 oranında, Kanal 7 kanalının 32 haberinde \%15,4 oranında, Star Tv kanalının 18 haberinde \%8,7 oranında, Kanal D kanalının 4 haberinde $\% 1,9$ oranında, Atv kanalının 11 haberinde \%5,3 oranında, Fox kanalında ise herhangi bir suç teşkil edecek şiddet haberi bulunmadığ 1 bulgusuna ulaşılmıştır. Bu doğrultuda en fazla suç unsuru barındıran kanalın Show Tv, en az suç unsuru barındıran kanalın ise Atv ve Fox Tv olduğunu söyleyebiliriz.

Tablo 9: Birbirlerini Tanıma

\begin{tabular}{c|c|c}
\hline Birbirlerini Tanıma & Sayı & Yüzde \\
\hline Tanımıyor & 192 & 92,3 \\
\hline Tanıyor & 13 & 6,3 \\
\hline Kodlanamaz & 3 & 1,4 \\
\hline Toplam & 208 & 100,0 \\
\hline
\end{tabular}

İncelenen dönemlerdeki süre içerisinde kanallardaki şiddet haberlerinde yer alan aktörlerin birbirlerini tanıyıp, tanımadıklarına ilişkin olarak; toplam 208 haber içerisinde, 192 haberde $\% 92,3$ oranında şiddet uygulayanlar ve uğrayanlar birbirlerini tanımamaktadır. 13 haberde birbirlerini tanıyan kişiler arasında yaşanan $\% 6,3$ oranında şiddet, 3 haberde ise $\% 1,4$ oranında şiddet haberlerindeki aktörlerin birbirlerini tanıyıp, tanımadıkları kodlanamamıştır. Genel olarak bakıldığında şiddet olaylarının en çok birbirlerini tanımayan kişiler arasında gerçekleştiği sonucu çıkmaktadır.

Tablo 10: Şiddetçi Ünlü mü?

\begin{tabular}{c|c|c}
\hline Şiddetçi Ünlü mü? & Say1 & Yüzde \\
\hline Ünlü Değil & 203 & 97,6 \\
\hline Ünlü & 3 & 1,4 \\
\hline Kodlanamaz & 2 & 1,0 \\
\hline Toplam & 208 & 100,0 \\
\hline
\end{tabular}

Şiddet haberlerinin incelendiği dönemde yer alan aktörlere bakıldığında; şiddet uygulayan aktörler toplam 208 haber içerisinde, 203 tane haberdeki aktörlerin \%97,6 oranında ünlü olmayan, 3 tane haberdeki aktörlerin \%1,4 oranında ünlü, 2 tane haberdeki aktörlerin ise $\% 1,0$ oranında kodlanamaz 
olduğu sonucuna ulaşılmıştır. Genel olarak bakıldığında, toplam 208 şiddet haberi içerisindeki aktörlerin büyük çoğunluğunu ünlü olmayan kişilerden oluştuğundan ünlü olmanın engelleyici bir unsur olarak ortaya çıkmasına neden olsa da aslında şiddetin toplumun bütün bireylerin birer şiddet potansiyeli barındırdığı söylenebilir.

Tablo 11: Şiddete Uğrayan Ünlü mü?

\begin{tabular}{c|c|c}
\hline Şiddete Uğrayan Ünlü mü? & Say1 & Yüzde \\
\hline Ünlü Değil & 188 & 90,4 \\
\hline Kodlanamaz & 18 & 8,7 \\
\hline Ünlü & 2 & 1,0 \\
\hline Toplam & 208 & 100,0 \\
\hline
\end{tabular}

Örneklemin seçilmiş olduğu dönemde yer alan şiddete uğrayan aktörlere bakıldığında; toplam 208 haber içerisinde 188 haberdeki şiddete uğrayan aktörler \%90,4 oranında, 18 tane haberde şiddete uğrayan aktörler $\% 8,7$ oranında, 2 haberde ise şiddete uğrayan aktörlerin oran $1 \% 1,0$ olduğu sonucuna ulaşılmıştır.

Tablo 12: Şiddetçinin İşi

\begin{tabular}{c|c|c}
\hline Şiddetçinin İşi & Sayı & Yüzde \\
\hline Kodlanamaz & 176 & 84,6 \\
\hline Asker & 16 & 7,7 \\
\hline Polis & 8 & 3,8 \\
\hline Dolmuş Şoförü & 5 & 2,4 \\
\hline Politikacı & 2 & 1,0 \\
\hline İş Adamı & 1 & 0,5 \\
\hline Toplam & 208 & 100,0 \\
\hline
\end{tabular}

İncelenen dönemdeki kanallar kapsamında şiddet uygulayan aktörlerin mesleki dağılımına bakıldığında; 176 haberde \%84,6 oranında şiddet haberlerinde şiddet uygulayıcısının mesleki durumun kodlanamaz olduğu söylenebilir. Diğer meslekler; 16 haberde şiddet uygulayıcısının asker \%7,7 oranında, 8 haberde şiddet uygulayıcısının polis $\% 3,8$ oranında, 5 haberde şiddet uygulayıcısının dolmuş şoförü \%2,4 oranında, 2 haberde şiddet uygulayıcısının politikacı $\% 1,0$ oranında, 1 haberde ise $\% 0,5$ oranında şiddet uygulayıcısının iş adamı olduğu sonucuna ulaşılmıştır.

Tablo 13: Şiddete Uğrayanın İşi

\begin{tabular}{c|c|c}
\hline Şiddete Uğrayanın İşi & Sayı & Yüzde \\
\hline Kodlanamaz & 166 & 79,8 \\
\hline Asker & 18 & 8,7 \\
\hline Polis & 6 & 2,9 \\
\hline Doktor & $5 * 2$ & $2 * 2,4$ \\
\hline Öğrenci & \multirow{2}{*}{$3 * 0,5$} \\
\hline Bekçi & \multirow{2}{*}{$1 * 3$} & 100,0 \\
\hline Taksici & & \\
\hline Okul Müdürü & 208 & \\
\hline Toplam & &
\end{tabular}


Örneklem olarak belirlenen ana haber bültenlerinin şiddet haberlerinde, şiddete uğrayan aktörlerin mesleki dağılımına bakıldığında; toplam 208 haber içerisinde 166 haberde şiddete uğrayanın mesleki durumun kodlanamaz olduğu söylenebilir. Diğer meslekler; 18 haberde şiddete uğrayanın asker $\% 8,7$ oranında, 6 haberde şiddete uğrayanın polis \%2,9 oranında, $5 * 2(10)$ haberde şiddete uğrayanın doktor ve öğrenci $\% 2,4 * 2(\% 4,8)$ oranında, $1 * 3(3)$ haberde ise $\% 0,5 * 3(\% 1,5)$ oranında şiddete uğrayanın bekçi, taksici, okul müdürü olduğu sonucuna ulaşılmıştır.

Tablo 14: Şiddete Uğrayanın Statüsü

\begin{tabular}{c|c|c}
\hline Şiddete Uğrayanın Statüsü & Say1 & Yüzde \\
\hline Kodlanamaz & 163 & 78,4 \\
\hline Alt & 39 & 18,8 \\
\hline Üst & 6 & 2,9 \\
\hline Toplam & 208 & 100,0 \\
\hline
\end{tabular}

Ele alınan tarih aralığındaki kanallardaki şiddet ögelerinin analizleri sonucunda, şiddete uğrayanın statüsü 163 haberde $\% 78,4$ oranında kodlanamaz olduğu görülmüştür. Şiddet maruz kalan kişilerin diğer statü dağılımları; 39 haberde $\% 18,8$ oranında alt statüde, 6 haberde $\% 2,9$ oranın da ise üst statüdeki bireyler olduğu söylenebilir.

Tablo 15: Şiddetçinin Statüsü

\begin{tabular}{c|c|c}
\hline Şiddetçinin Statüsü & Say1 & Yüzde \\
\hline Kodlanamaz & 172 & 82,7 \\
\hline Alt & 33 & 15,9 \\
\hline Üst & 3 & 1,4 \\
\hline Toplam & 208 & 100,0 \\
\hline
\end{tabular}

Toplam 208 şiddet haberlerinde, şiddet uygulayıcısı aktörlerin 172 haberde $\% 82,7$ oranında kodlanamaz olduğu sonucu çıkmıştır. Şiddet uygulayıcısının 33 haberde $\% 15,9$ oranında alt statüde, 3 haberde $\% 1,4$ oranında ise üst statüdeki bireyler olduğu söylenebilir. Genel olarak bakıldığında incelenen haberlerdeki bireylerin statüsünün kodlanamaz olduğu sonucuna varılmış olsa da, birey hangi statüde olursa olsun hem şiddet uygulayan hem de uğrayan konumda olabileceği söz konusudur.

Tablo 16: Şiddetçinin Cinsiyeti

\begin{tabular}{c|c|c}
\hline Şiddetçinin Cinsiyeti & Say1 & Yüzde \\
\hline Erkek & 116 & 55,8 \\
\hline Kodlanamaz & 85 & 40,9 \\
\hline Her İkisi de & 5 & 2,4 \\
\hline Kadın & 2 & 1,0 \\
\hline Toplam & 208 & 100,0 \\
\hline
\end{tabular}

İncelenen kanallardaki şiddet olaylarının cinsiyete göre analiz edildiği tablo 19'a bakıldığı zaman şiddet uygulayan aktörlerin büyük çoğunluğunun cinsiyetinin 116 haberde $\% 55,8$ oranında erkek olduğu sonucuna ulaşılmıştır. 85 haberde $\% 40,9$ oranında ise şiddet olayları toplu bir şekilde gerçekleştirildiği için şiddet aktörleri cinsiyet bakımından kodlanamamıştır. 5 haberde hem erkek hem 
de kadın $\% 2,4$ oranında cinsiyeti kodlanırken, 2 haberde ise kadın $\% 1,0$ oranında cinsiyeti kodlanmıştır. Genel olarak şiddet haberlerinde şiddet uygulayan kişilerin erkek olduğu söylenebilir.

Tablo 17: Şiddete Uğrayanın Cinsiyeti

\begin{tabular}{c|c|c}
\hline Şiddete Uğrayanın Cinsiyeti & Sayı & Yüzde \\
\hline Erkek & 102 & 49,0 \\
\hline Her İkisi de & 49 & 23,6 \\
\hline Kodlanamaz & 37 & 17,8 \\
\hline Kadın & 20 & 9,6 \\
\hline Toplam & 208 & 100,0 \\
\hline
\end{tabular}

Ele alınan kanallarda 208 tane şiddet haberinden 102 tanesinde erkek \%49,0 oranında şiddete uğradığı söylenebilir. 49 tane şiddet haberinde \%23,6 oranında hem erkek hem de kadın, 20 tane haberde ise $\% 9,6$ oranında kadının şiddete uğradığı, 37 haberde ise $\% 17,8$ oranında şiddete uğrayanın cinsiyeti tespit edilemeyip kodlanamaz olarak işaretlenmiştir. Elde edilen bulgulara göre şiddet uygulayan ve şiddete uğrayanın cinsiyeti erkek olduğu söylenebilir.

Tablo 18: Olay Yeri

\begin{tabular}{c|c|c}
\hline Olay Yeri & Say1 & Yüzde \\
\hline İstanbul & 43 & 20,7 \\
\hline Kodlanamaz & 23 & 11,1 \\
\hline Antalya & 14 & 6,7 \\
\hline Adana & 10 & 4,8 \\
\hline Batman & 8 & 3,8 \\
\hline Ankara & \multirow{2}{*}{$5 * 2$} & $2 * 2,4$ \\
\hline Kocaeli & & \\
\hline İzmir & & \multirow{2}{*}{$7 * 1,9$} \\
\cline { 1 - 1 } Adiyaman & $4 * 7$ & \\
\cline { 1 - 1 } Manisa & & \\
\cline { 1 - 1 } Amerika & & $\mathbf{1 0 0 , 0}$
\end{tabular}

İncelenen haberler kapsamında toplam 208 haberde şiddetin meydana geldiği yer hakkında elde edilen verilere bakıldığında; 43 haberle \%20,7 oranında en çok İstanbul'da şiddet olaylarının meydana geldiği söylenebilir. 23 haberde ise $\% 11,1$ oranında şiddet olayının geçtiği şehir kodlanamamıştır. Diğer şehir ve ülkelere bakılacak olursa; 14 haberde \%6,7 oranında Antalya, 10 haber $\% 4,8$ oranında Adana, 8 haberde $\% 3,8$ oranında Batman, $5 * 2(10)$ haberde $\% 2,4 * 2(\% 4,8)$ oranında Ankara ve Kocaeli, $4 * 7$ (28) haberde $\% 1,9 * 7(\% 13,3)$ oranında ise İzmir, Adıyaman, Manisa şehirleri ve Amerika, Irak, Hindistan, Filistin ülkeleri şiddetin geçtiği olay yeri sonucu çıkmıştır. Tabloya yer verilemeyen diğer şehir ve ülkelere bakılırsa; 12 haberde \% 1,4 oranında Şanlıurfa, Siirt, Tokat, Konya şehirleri, 18 haberde \%1,0 oranında Burdur, Karaman, Karabük, Bursa, Diyarbakır, Kahramanmaraş, Hakkari, Düzce, Trabzon, Yunanistan, Endonezya, Suriye, Rusya, Peru, İran, Kandil, Afrin, Münbiç ilçe, şehir ve 
ülkeleri, 24 haber de ise \%0,5 oranında Denizli, Kayseri, Tunceli, Bilecik, Gümüşhane, Kars, Gaziantep, Aksaray, Bodrum, Isparta, Osmaniye, Aydın, Tekirdağ, Van, Sakarya, Samsun, Ordu, ve Mikronezya, Brezilya, Ukrayna, Moskova, İspanya, Romanya ve Çin ülkelerinde şiddet olaylarının geçtiği söylenebilir.

Tablo 19: Yerleşim Birimi

\begin{tabular}{c|c|c}
\hline Yerleşim Birimi & Say1 & Yüzde \\
\hline Şehir Merkezi & 158 & 76,0 \\
\hline Kırsal & 33 & 15,9 \\
\hline Kodlanamaz & 17 & 8,2 \\
\hline Toplam & 208 & 100,0 \\
\hline
\end{tabular}

Şiddet olaylarının yaşandığı yerleşim birimine göre analiz edildiğinde, toplam 208 şiddet içerikli haberin içerisinde, 158 haberin $\% 76,0$ oranında şehir merkezinde gerçekleştiği görülürken, 33 haberin ise $\% 15,9$ oranında kırsal alanda şiddet olaylarının yaşandığı söylenebilir. Bunun yanı sıra 17 haberin $\% 8,2$ oranında yerleşim birimi kodlanamamıştır.

Tablo 20: Olay Saati

\begin{tabular}{c|c|c}
\hline Olay Saati & Say1 & Yüzde \\
\hline Gündüz & 167 & 80,3 \\
\hline Gece & 34 & 16,3 \\
\hline Hem Gündüz Hem Gece & 5 & 2,4 \\
\hline Kodlanamaz & 2 & 1,0 \\
\hline Toplam & 208 & 100,0 \\
\hline
\end{tabular}

Zaman dilimine göre elde edilen bulgularda, şiddet olaylarının 167 haberde görüldüğü üzere en çok $\% 80,3$ oranında gündüz saatlerinde yaşandığı saptanmıştır. Diğer oranlara bakıldığında; 34 haber $\% 16,3$ oranında gece saatinde, 5 haber $\% 2,4$ oranında hem gündüz hem gece saatinde, 2 haber ise $\% 1,0$ oranında kodlanamaz olduğu görülmektedir. Genel olarak örneklem alınan tarihler arasındaki kanallarda şiddet olayları gündüz saatinde gerçekleştiği söylenebilir.

Tablo 21: Kanallar ve Olay Saati

\begin{tabular}{c|c|c|c|c}
\hline $\begin{array}{c}\text { Kanallar ve Olay } \\
\text { Saati }\end{array}$ & Kodlanamaz & Gündüz & Gece & Hem Gündüz Hem Gece \\
\hline Atv & - & 13 & - & 5 \\
\hline Star Tv & - & 39 & 6 & - \\
\hline Show Tv & 1 & 37 & 11 & - \\
\hline Kanal D & 1 & 15 & 2 & - \\
\hline Fox Tv & - & 5 & 1 & - \\
\hline Kanal 7 & - & 58 & 14 & - \\
\hline Toplam (208) & 2 & 167 & 34 & 5 \\
\hline
\end{tabular}

Ele alınan dönemler kapsamında, kanallar özelinde şiddet olaylarının saatine bakılırsa; toplam 208 haberde, Atv, Star Tv, Fox Tv, Kanal 7 kanalında şiddet haberi görülmezken, Show Tv ve Kanal D 
kanalında 1 'er tane şiddet haberi $\% 0,5 * 2(\% 1)$ oranında şiddet olayının saati kodlanamaz olarak işaretlenmiştir. Şiddet haberlerinde olay saatinin gündüz olduğu haberlere bakılacak olursa; Atv kanalının 13 haberi \%6,3 oranında, Star Tv kanalının 39 haberi \%18,8 oranında, Show Tv kanalının 37 haberi \%17,8 oranında, Kanal D kanalının 15 haberi \%7,2 oranında, Fox Tv kanalının 5 haberi 2,4 oranında, Kanal 7 kanalının 58 haberi ise \%27,9 oranında olduğu söylenebilir. Şiddet haberlerinde olay saatinin gece olduğu haberlere bakılacak olursa; Atv kanalının haber bülteninde şiddet olaylarının gece saati meydana gelmediği görülürken, Star Tv kanalının 6 haberinin \%2,9 oranında, Show Tv kanalının 11 haberinin \%5,3 oranında, Kanal D kanalının 2 haberinin \%1,0 oranında, Fox Tv kanalının 1 haberinin $\% 0,5$ oranında, Kanal 7 kanalının ise 14 haberinin \%6,7 oranında şiddet olaylarının gece meydana geldiği söylenebilir. Şiddet haberlerinde olay saatinin hem gündüz hem gece olduğu haberlere bakılacak olursa; sadece Atv kanalının 5 haberi \%2,4 oranında hem gündüz hem de gece gerçekleşmiş olduğu bulgusuna ulaşılmıştır. Diğer kanallarda ise hem gündüz hem gece şiddet olayları meydana gelmemiştir. Bu noktada; kanallar içerisinde en yoğun şiddet eylemlerinin yaşandığı 58 haber ile Kanal 7 kanalında gündüz saatinde gerçekleşmiştir, en az şiddet eyleminin gerçekleştiği gündüz saatinde 5 haber ile Fox Tv'de gerçekleştiği söylenebilir. Gece saatinde ise; en fazla 14 haber ile Kanal 7, hiç şiddet unsurunun barınmadığı Atv'de ise herhangi bir olay bulgusuna rastlanmamıştır.

Tablo 22: Şiddet Aleti ve Sayısı

\begin{tabular}{c|c|c}
\hline Şiddet Aleti ve Sayı1 1 & Say1 & Yüzde \\
\hline Silah & 58 & 21,2 \\
\hline Araba & 41 & 15,0 \\
\hline Bomba & 36 & 13,2 \\
\hline Kodlanamaz & 19 & 7,0 \\
\hline Yumruk & 18 & 6,6 \\
\hline Tekme & 14 & 5,1 \\
\hline Biçak & 12 & 4,4 \\
\hline Sel & 8 & 2,9 \\
\hline Motosiklet & $7 * 2$ & $2,6 * 2$ \\
\hline Sopa & 5 & 1,8 \\
\hline Taş & & $1,5 * 3$ \\
\hline Biber Gazı & $4 * 3$ & 100,0 \\
\hline Satır & & \\
\hline Kap1 & 273 & \\
\hline Toplam & & \\
\hline
\end{tabular}

Örneklem olarak belirlenen ana haber bültenlerinde sunulan şiddet olaylarında şiddet aleti olarak kullanılan araçlar arasında toplam 208 haber içerisinde en çok 58 tane $\% 21,2$ oranında silah aleti kullanıldığı bulgusu saptanmıştır. Diğer şiddet haberlerinde kullanılan şiddet aletlerine bakıldığında; 41 tane araba \%15,0 oranında, 36 tane bomba \%13,2 oranında, 18 tane yumruk \%6,6 oranında, 14 tane tekme $\% 5,1$ oranında, 12 tane biçak $\% 4,4$ oranında, 8 tane sel $\% 2,9$ oranında, $7 * 2$ (14) tane motosiklet ve sopa $\% 2,6 * 2(\% 5,2)$ oranında, 5 tane taş $\% 1,8$ oranında, $4 * 3$ (12) tane ise biber gazı, satır, kapı $\% 1,5 * 3(\% 4,5)$ oranında şiddet aleti bulunduğu söylenebilir. Tabloda yer almayan şiddet haberleri içerisinde yer alan şiddet aletlerine bakıldığında; $3 * 4$ (12) tane köpek, kimyasal gaz, balta, ateş \%1,1 oranında, $2 * 6$ (12) tane sandalye, firtına, heyelan, deprem, kemer, jop \%0,7 oranında, $1 * 12$ (12) tane çakmak, uçak, şarj aleti, tren, lpg tankı, trafo, testere, kazan, telefon, hortum, yıldırım, dart oku \%0,4 
oranında şiddet aleti bulunduğu sonucuna ulaşılmıştır. Genel olarak 208 şiddet haberi içerisinde toplam 273 tane şiddet aleti olduğu gözlenmiştir.

Tablo 23: Şiddet Biçimi ve Sayısı

\begin{tabular}{c|c|c}
\hline Şiddet Biçimi ve Sayıs1 & Sayı & Yüzde \\
\hline Silahlı Saldırı & 48 & 16,6 \\
\hline Yaralama & 47 & 16,2 \\
\hline Darp & 30 & 10,3 \\
\hline Araba kazası & 26 & 9,0 \\
\hline Patlama & $23 * 2$ & $7,9 * 2$ \\
\hline Bombalama & 18 & 6,2 \\
\hline Doğal Afet & 15 & 5,2 \\
\hline Kodlanamaz & 14 & 4,8 \\
\hline Cinayet & 11 & 3,8 \\
\hline Çatışma & 9 & 3,1 \\
\hline Bıçaklı Saldırı & 8 & 2,8 \\
\hline Motosiklet kazası & 5 & 1,7 \\
\hline Isırma & 290 & 100 \\
\hline Toplam & &
\end{tabular}

Toplam incelenen 208 şiddet haberi, şiddet biçimini analiz etmek amacıyla incelendiğinde şiddet olaylarında en çok 48 tane silahlı saldırı \%16,6 oranında ve 47 tane yaralama \%16,2 oranında şiddet biçiminin gerçekleştiğini söylenebilir. Diğer şiddet haberlerinde şiddet biçimlerine bakılırsa; 30 tane darp \% 10,3 oranında, 26 tane araba kazas $1 \% 9,0$ oranında, $23 * 2$ (46) tane patlama ve bombalama $\% 7,9 * 2(15,8)$ oranında, 18 tane doğal afet $\% 6,2$ oranında, 14 tane cinayet $\% 4,8$ oranında, 11 tane çatışma \%3,8 oranında, 9 tane bıçaklı saldırı \%3,1 oranında, 8 tane motosiklet kazası $\% 2,8$ oranında, 5 tane 1sırma $\% 1,7$ oranında, 15 tane ise $\% 5,2$ oranında şiddet haberlerinde şiddet biçiminin kodlanamaz olarak işaretlendiği sonucuna ulaşılmıştır. Tabloda yer almayan şiddet haberleri içerisinde yer alan şiddet biçimlerine bakıldığında; $2 * 4$ (8) tane yangın, tecavüz, yere yatırma, tren kazası $\% 0,7 * 4(\% 2,8)$ oranında, $1 * 5(5)$ tane ise uçak kazası, kaçırma/alıkoyma, hendek, yerde sürükleme, boğma $\% 0,3 * 5$ $(\% 1,5)$ oranında şiddet biçimi olduğu söylenebilir. Genel olarak toplam 208 şiddet haberi içerisinde 290 tane şiddet biçimi olduğu sonucuna ulaşılmıştır.

Tablo 24: Haberlerdeki Şiddet Adeti

\begin{tabular}{l|c|c|c|c}
\hline & Say1 & En Düşük & En Fazla & Ortalama \\
\hline Şiddet Adeti & 208 & 1,00 & 60,00 & 9,16 \\
\hline
\end{tabular}

Televizyondaki ana haber bültenlerinde şiddet örüntülerini açığa çıkarmak amacıyla gerçekleştirilen incelemede, şiddet adeti tablosuna bakıldığında, şiddet haberlerinde en az 1, en fazla 60 ve ortalama 9,16 şiddet sahnesinin gösterildiği sonucuna ulaşı1mıştır. 


\begin{tabular}{c|c|c}
\hline \multicolumn{3}{|c}{ Tablo 25: Show Tv Şiddet Süresi } \\
\hline Gün & Haber Sayı1 & Şiddet Süresi (Yüzde) \\
\hline 1 Ekim 2018 & 7 & $\% 15,55$ \\
\hline 2 Ekim 2018 & 15 & $\% 23,04$ \\
\hline 3 Ekim 2018 & 9 & $\% 33,88$ \\
\hline 4 Ekim 2018 & 10 & $\% 38,93$ \\
\hline 5 Ekim 2018 & 8 & $\% 34,43$ \\
\hline
\end{tabular}

Araştırmanın örneklemini oluşturan ana haber bültenlerinde şiddet haberlerinin diğer haberlere kıyasla toplam süre içerisinde ne kadar süre yer aldığını analiz etmek amacı ile yapılan analizde, Show Tv kanalında şiddet süresinin en çok 4 Ekim 2018'de en az ise 1 Ekim 2018'de olduğu sonucuna ulaşılmıştır.

Tablo 26: Kanal D Şiddet Süresi

\begin{tabular}{c|c|c}
\hline Gün & Haber Sayıs1 & Şiddet Süresi (Yüzde) \\
\hline 1 Ekim 2018 & 4 & $\% 14,95$ \\
\hline 2 Ekim 2018 & 3 & $\% 10,55$ \\
\hline 3 Ekim 2018 & 2 & $\% 8,71$ \\
\hline 4 Ekim 2018 & 3 & $\% 11,83$ \\
\hline 5 Ekim 2018 & 5 & $\% 17,14$ \\
\hline
\end{tabular}

Araştırmanın örneklemini oluşturan ana haber bültenlerinde şiddet haberlerinin diğer haberlere kıyasla toplam süre içerisinde ne kadar süre yer aldığını analiz etmek amacı ile yapılan analizde, Kanal D kanalında şiddet süresinin en çok 5 Ekim 2018 'de en az ise 3 Ekim 2018'de olduğu sonucuna ulaşılmıştır.

Tablo 27: Star Tv Şiddet Süresi

\begin{tabular}{c|c|c}
\hline Gün & Haber Say1S1 & Şiddet Süresi (Yüzde) \\
\hline 1 Ekim 2018 & 12 & $\% 33,81$ \\
\hline 2 Ekim 2018 & 6 & $\% 18,08$ \\
\hline 3 Ekim 2018 & 7 & $\% 27,66$ \\
\hline 4 Ekim 2018 & 8 & $\% 23,67$ \\
\hline 5 Ekim 2018 & 12 & $\% 34,76$ \\
\hline
\end{tabular}

Araştırmanın örneklemini oluşturan ana haber bültenlerinde şiddet haberlerinin diğer haberlere kıyasla toplam süre içerisinde ne kadar süre yer aldığını analiz etmek amacı ile yapılan analizde, Star Tv kanalında şiddet süresinin en çok 5 Ekim 2018'de en az ise 2 Ekim 2018'de olduğu sonucuna ulaşılmıştır.

Tablo 28: Fox Tv Şiddet Süresi

\begin{tabular}{c|c|c}
\hline Gün & Haber Sayıs1 & Şiddet Süresi (Yüzde) \\
\hline 1 Ekim 2018 & 0 & $\% 0$ \\
\hline 2 Ekim 2018 & 1 & $\% 3,60$ \\
\hline 3 Ekim 2018 & 1 & $\% 4,35$ \\
\hline 4 Ekim 2018 & 2 & $\% 11,43$ \\
\hline 5 Ekim 2018 & 2 & $\% 11,23$ \\
\hline
\end{tabular}

Araştırmanın örneklemini oluşturan ana haber bültenlerinde şiddet haberlerinin diğer haberlere kıyasla toplam süre içerisinde ne kadar süre yer aldığını analiz etmek amacı ile yapılan analizde, Fox Tv kanalında şiddet süresinin en çok 4 Ekim 2018'de, 1 Ekim 2018'de ise hiç şiddet haberi bulunmadığını sonucuna ulaşılmıştır. 


\begin{tabular}{c|c|c}
\hline & Tablo 29: Kanal 7 Şiddet Süresi \\
\hline Gün & Haber Say1s1 & Şiddet Süresi (Yüzde) \\
\hline 1 Ekim 2018 & 17 & $\% 43,26$ \\
\hline 2 Ekim 2018 & 13 & $\% 23,83$ \\
\hline 3 Ekim 2018 & 10 & $\% 36,02$ \\
\hline 4 Ekim 2018 & 15 & $\% 39,80$ \\
\hline 5 Ekim 2018 & 18 & $\% 42,50$ \\
\hline
\end{tabular}

Araştırmanın örneklemini oluşturan ana haber bültenlerinde şiddet haberlerinin diğer haberlere kıyasla toplam süre içerisinde ne kadar süre yer aldığını analiz etmek amacı ile yapılan analizde, Show Tv kanalında şiddet süresinin en çok 1 Ekim 2018'de en az ise 2 Ekim 2018'de olduğu sonucuna ulaşılmıştır.

Tablo 30: Atv Șiddet Süresi

\begin{tabular}{c|c|c}
\hline Gün & Haber Say1s1 & Şiddet Süresi (Yüzde) \\
\hline 1 Ekim 2018 & 5 & $\% 29,91$ \\
\hline 2 Ekim 2018 & 1 & $\% 8,87$ \\
\hline 3 Ekim 2018 & 2 & $\% 10,23$ \\
\hline 4 Ekim 2018 & 4 & $\% 32,39$ \\
\hline 5 Ekim 2018 & 6 & $\% 33,95$ \\
\hline
\end{tabular}

Araştırmanın örneklemini oluşturan ana haber bültenlerinde şiddet haberlerinin diğer haberlere kıyasla toplam süre içerisinde ne kadar süre yer aldığını analiz etmek amacı ile yapılan analizde, Atv kanalında şiddet süresinin en çok 5 Ekim 2018'de en az ise 1 Ekim 2018'de olduğu sonucuna ulaş1lmıştır.

\section{Sonuç ve Değerlendirme}

Günümüzde görsel basın olan televizyon bireylerin yaşam tarzlarına doğrudan yön veren etkili bir medya konumundadır. Televizyon ekranlarında her geçen gün etkisini artıran şiddet ögeleri, kadın programlarında, komedi veya dram filmlerinde, yarışma programlarında, dizilerde ve hatta ana haber bültenlerinde etkisini göstermektedir. Özellikle ana haber bültenlerindeki haberler, bireylerin düşüncelerindeki gücü göz önüne alındığında vermiş olduğu mesajlar bireyler üzerinde oldukça büyük etkiler yaratmaktadır. Haberdeki şiddet ögeleri en küçük ayrıntısına kadar; yananların vücutları tamamen açık bir şekilde, trafik kazasında yaralananlar can çekişirken, şiddet taraflarının yakarışlarıağlamaları verilmektedir. Hatta çeşitli programlara şiddet mağdurları çağırılarak, canlı yayında olay tekrar canlandırılmaktadır. Bu noktada medya şiddetin yeniden üretilmesi ve sıradanlaştırılmasında önemli bir rol oynamaktadır. Araştırmada medyada özellikle ana haber bültenlerinde şiddet ögelerinin mesaj sistem çözümlemesi ile açığa çıkarılması amaçlanmıştır.

Araştırma bulguları göz önüne alındığında; Atv, Star, Show Tv, Kanal D, Fox, Kanal 7 kanallarında bir hafta süresince $(1.10 .2018$ - 5.10.2018) tarihleri arasında yayınlanan ana haber bültenlerinde diğer tarihlere oranla şiddet içeriğinin en çok 5.10 .2018 tarihinde $\% 24,5$ oranında olduğu görülmektedir.

Ana haber bültenlerine ilişkin mesaj sistem çözümlemesinin süreklilik kategorisinde haberde şiddetin ayrı olarak değil, devamlı sunulduğu tespit edilmiştir. Bültenlerde şiddet haberlerinin mizah ögesi barındırmayarak, devamlı olarak ciddi tonda verildiği ortaya çıkmıştır. İncelenen şiddet içerikli haberlerin çok büyük bir oranda $(\% 61,1)$ kaza olmadığ 1 , kasten gerçekleştirilmiş eylemlerden oluştuğu görülmüştür.

Toplam 208 şiddet içerikli haber içerisinde 88 tanesi kanun birimleri olarak ele alınan aktörlerin (polis, asker, güvenlik görevlisi vb.) \%43,2 oranında resmi bir şekilde görüldüğü sonucu ortaya çıkmıştır. Kanun birimlerinin şiddet eylemlerinde konumlandırıldığ 208 haberin 120 'unda polisin şiddet aktörü olarak kodlanamayacağı sonucu ortaya çıkmasının yanı sıra polislerin aktör olarak yer aldığı haberlere bakıldığında, 8 haberde şiddetin uygulayıcısı, 5 haberde şiddete maruz kalırken, 68 haber de 
ise polis şiddete uğramamakta ve şiddet uygulamamaktadır. Ana haber bültenlerinde sunulan şiddet haberlerinin, \%65,4'ü suç niteliği taşırken, \%34,1'i herhangi bir suç niteliği taşımamaktadır. Haberlerde, suç niteliğinin fazla çıkması ele alınan dönemdeki etkili olan olayların (terör, şehit haberleri, savaş haberleri) yer almasının etkili olduğu söylenilebilir. Diğer kanallara kıyasla Bu doğrultuda en fazla suç unsuru barındıran kanalın Show Tv, en az suç unsuru barındıran kanalın ise Atv ve Fox Tv olduğunu söyleyebiliriz.

Şiddet haberlerinde, aktörlerin birbirlerini tanıyıp tanımadıkları ile ilgili incelenen kısım \%1,4 oranında kodlanamaz sonucu çıkmıştır. Baktığımız zaman toplam haberler içerisinde şiddet uygulayanlar ve uğrayanlar \%92,3 oranında birbirlerini tanımamaktadır. Birbirlerini tanıyan kişiler arasında yaşanan şiddet ise \%6,3 olarak tespit edilmiştir. Bu noktadan hareket ile şiddet olaylarının en çok birbirlerini tanımayan bireyler arasında gerçekleştiği sonucuna varabiliriz.

Haberin seçildiği dönemde şiddet uygulayan aktörler \%97,6 oranında ünlü olmayan, \%1,4’ü ise ünlü kişilerden oluşmaktadır. Şiddete uğrayan aktörler ise, $\% 90,4$ oranında ünlü olmayan, \%1,0’i ise ünlü kişilerden oluşmaktadır. Şiddet haberlerindeki şiddetçinin işi kategorisindeki aktörlerin meslek dağılımlarına baktığımız zaman; 176 haberde $\% 84,6$ oranında kodlanamaz olduğu görülmüştür. Şiddete uğrayanın aktörlerin kategorisindeki meslek dağılımına bakıldığı zaman; 166 haberde \%79,9 oranında kodlanamaz olduğu görülmüştür. Analiz ışığında, şiddetin uygulayıcısı ve uğrayan olarak bireylerin mesleklerinde anlamlı bir farklılaşmaya rastlanamamıştır. Bunun yanı sıra incelenen şiddet haberlerinde toplu olarak gerçekleştirilen şiddet eylemlerinde azımsanmayacak derecede, çoğu haberde şiddete uygulayıcısı ve şiddete uğrayanın meslek bilgileri verilmediğini de belirtmek gerekmektedir. Toplumsal sınıf ve statü kategorisine bağlı olarak yapılan kodlamalarda şiddet uygulayan ve şiddete uğrayanlar kodlanamaz olduğu sonucuna ulaşılmıştır. Şiddet haberleri şiddeti uygulayan ve şiddete uğrayan olarak cinsiyet bakımından incelendiğinde, her iki kategoride de erkek aktörlerin yer aldığı sonucuna ulaşılmıştır.

Şiddet olaylarının en fazla gerçekleştiği yere baktığımız zaman; \%20,7 oranında İstanbul gelirken, olayların yaşandığı yerleşim birimine göre 158 haberde $\% 76,0$ oranında şehir merkezinde gerçekleştiği görülürken, 33 haberde ise $\% 15,9$ oranında kırsal alanda şiddet olaylarının yaşandığını söyleyebiliriz. Yaşanan şiddet olaylarının zaman dilimine göre elde edilen bulgularda, şiddet olaylarının 167 haberde görüldüğü üzere en çok \% 80,3 oranında gündüz saatlerinde yaşandığ 1 saptanmıştır. Gündüz saatlerinde yaşanmasının nedenini bireyler arasındaki ilişkilerin daha yoğun olmasının kaynaklı olarak çatışma ve gerilimlerin yaşanmasına, özellikle de protestolara bağlı olarak yapılan müdahelerden kaynaklı şiddet olaylarının gerçekleşebileceği ihtimali de mevcuttur.

Yaşanan şiddet olaylarının büyük bir kısmı silahlı olarak gerçekleştirilmiştir. Ele alınan dönemde incelenen kanallarda silahla, insan hayatına kasıtlı olarak ağır ve ciddi şiddet eylemlerinin sonuçları olduğu görülmüştür. Ana haber bültenlerinde incelenen haberlerde, şiddet adetine bakıldığ1 zaman en az 1, en fazla 60 ve ortalama 9,16 şiddet sahnesine yer verildiği bulgusuna ulaşılmıştır. Ele alınan haberler kanal özelinde değerlendirildiğinde ise, 5 günlük süre içerisinde şiddet sunumunun en fazla Kanal 7 kanalında rastlanırken, şiddet sahnesi en az Fox Tv'de gözlenmiştir.

Bütün bunlar bağlamında görsel basında yer alan şiddet içerikli haberlere ilişkin bulgular ve sonuçlar doğrultusunda ve araştırmacının, araştırma sürecinde kazandığı deneyimlerine dayanarak şu önerilerde bulunmak mümkündür:

Gerek gündelik hayatımızda gerekse medyada şiddet konusunda çalışmalar yapan birimlerin tüm üniversitelerde yaygınlaştırılarak, üniversitelerden mezun olan bireylerin ulusal bir şiddet bilinci yaratılmalıdır. Benzer şekilde iletişim fakültelerinde de şiddet dersleri yaygınlaştırılarak, yetiştirilen öğrencilerin özellikle medyada şiddet konusunda tam donanımlı bir şekilde mezun olmaları sağlanmalıdır. 
Yapılan haberlerde toplumda var olan şiddetin içselleştirilmesi ve bu tür davranışların normal, olağan bir durum gibi gösterilmemesinin yanı sıra sansasyonel ve magazinel olarak haberleştirilmesi eğiliminden uzak durulmalıdır.

Şiddeti daha genel anlamda ele alacak olursak, özellikle araştırma kapsamında ana haber bültenlerinde hemen hemen her kanalda şiddet haberlerinin kodlanması sırasında hayvanlara yönelik şiddetin anımsanmayacak derecede olduğu gözlenmiştir. Bu noktada her türlü canlıya karşı (bitkiler, ağaçlar, çiçekler) şiddetin önlenmesi noktasında öneri geliştirmek gerekir. Gerbner'in şiddet tanımından hareketle hayvanlara ve diğer çeşitli canlılara karşı yönelik şiddet eylemleri araştırmaya dahil edilmemiștir. Televizyon bireylerin hayatında büyük bir bölümünü olușturduğu noktasından hareketle, büyük sorunlarından birisi haline gelen hayvanlara yönelik şiddet eylemleri de toplumu derinden etkilemektedir. Bu noktada hayvanlara yönelik şiddet eylemlerinin de göz ardı edilmemesi gerektiği söylenilebilir.

Televizyon kuruluşları sorumlu yayıncılık anlayışı doğrultusunda bireylerin özellikle de çocukların ekran başında olduğu saatlerde, onları olumsuz etkilenmelerine sebep olabilecek yayınlara yer vermemelidirler. Şiddet içeren konu ve olayları mümkün olduğunca görselleștirmemek ve tekrar tekrar yayınlamamak oldukça önemlidir. Çünkü başta çocuklar olmak üzere yetişkinlerde korku, kayg1 ve daha birçok olumsuz duruma karşı duyarsızlaştırdığını söyleyebiliriz. Sonuç olarak televizyondaki şiddetin olumsuz etkilerinden korunabilmek için bireyler, yayıncılar ve RTÜK'ün işbirliği içerisinde çalışmalarını arttırarak ortak bir şekilde devam ettirmeleri önemli görünmektedir.

Bu çalışma Türkiye'deki ulusal yayın yapan televizyon kanallarındaki, ana haber bültenlerinde yer alan şiddet ögelerinin analizlerinden oluşmaktadır. Elde edilen bulgular televizyon özelinde yapılacak olan şiddet araştırmalarına faydalı olacağı düşünülmektedir. Ayrıca çalışma Anadolu Üniversitesi Sosyal Bilimler Enstitüsü Basın-Yayın Anabilim Dalı Doktora Programı Medyada Şiddet Araştırmaları dersi kapsamında Prof. Dr. Ömer Özer danışmanlığında yürütülmüştür. Çalışmaya olan katkısından dolayı teşekkür ederim.

\section{KAYNAKÇA}

Gerbner, G. vd. (1980). The Mainstreaming Of America: Violence Profile No:11. Journal Of Communication, 30 (3), 10-29.

Gümüş, A. (2006). Şiddet Türleri. Toplumsal Bir Sorun Olarak Şiddet Sempozyumu. Ankara: Eğitim Sen Yayınları, 13-37.

Kunczik, M. (1994), Gewalt Und Medien, Böhlau: Köln, Weimar, Wien.

Morgan, M. (1984). Heavy Television Viewing And Perceived Quality Of Life. Journalism Quarterly, (61), 499- 504.

Özer, Ö. (2004). Yetiştirme Kuramı: Televizyonun Kültürel İşlevlerinin İncelenmesi. Eskişehir: Anadolu Üniversitesi Yayınları.

Özer, Ö. (2007). Medya, Şiddet, Toplum. Eskişehir: Anadolu Üniversitesi Yayınları. 